\title{
Discussion on the Teaching Problems and Countermeasures of Ancient Chinese Literature Under the New Education Concept
}

Lu Yang

Xiangsihu College of Guangxi University for Nationalities, Nanning 540008, Guangxi, China. E-mail: yl13978681048@sina.com Project: The name of the project of educational reform within the school: The Exploration of China's Ancient Literature "Golden Class" Construction under the Background of "Internet + education" (the school education reform project number: 2019YJJG19).

Abstract: Ancient Chinese literature is an important part of Chinese language and literature. However, due to the lack of professional quality and teaching experience of most ancient Chinese literature teachers in China, there are many problems in the teaching of ancient Chinese literature, which hinders the improvement of students' comprehensive quality. In this regard, this paper discusses the teaching problems and coping strategies of ancient Chinese Literature under the new education concept, hoping to help improve the teaching quality of ancient Chinese literature in China.

Keywords: New Educational Ideas; Ancient Chinese Literature; Teaching Problems; Countermeasures

Ancient Chinese literature is a basic compulsory course for Chinese language and literature major in colleges and universities in China. The course consists of two parts: literary history and literary works. The main framework of literary development is built through literary history, and the fruitful achievements of ancient Chinese literature in various periods are reflected through literary works. In view of the fact that this course has many contents, a long time span, a long distance from the current social life and students' low interest in learning, how to carry out teaching activities more effectively has become a hot topic for teachers.

\section{Problems existing in the teaching of ancient Chinese literature under the new educational concept}

\subsection{The reduction of teaching hours cannot guarantee the teaching quality}

First of all, the teaching time of ancient Chinese literature involves 3000 years, and there are countless literary works in this long history; secondly, the teaching content and knowledge of ancient Chinese literature are very extensive. This means that the teaching task of ancient Chinese literature is very heavy. However, at present, the majority of Chinese language majors in colleges and universities pay more attention to the theoretical and practical teaching of students, while ignoring the accumulation of knowledge and innovation of views, leading to the general reduction of teaching hours of ancient Chinese literature. Under the background of the new education concept, although focusing on practical teaching is the development trend, for the subject of ancient Chinese literature, the reduction of teaching hours is not conducive to improving students' cultural literacy and teachers' teaching efficiency and quality.

\subsection{Not enough attention for the teaching of literary works}

Most colleges and universities in China will choose to arrange the teaching of literary history and literary works together

Copyright $\odot 2020$ Lu Yang

doi: 10.18686/ahe.v4i10.2930

This is an open-access article distributed under the terms of the Creative Commons Attribution Non-Commercial License (http://creativecommons. org/licenses/by-nc/4.0/), which permits unrestricted non-commercial use, distribution, and reproduction in any medium, provided the original work is properly cited. 
when they make the teaching plan of ancient Chinese literature. Most teachers of ancient Chinese literature will focus on the teaching of literary history. They think that literary works are only the auxiliary content of learning ancient Chinese literature, and even some teachers will give literary works to students by self-study. Ancient Chinese literature is a basic compulsory course for Chinese language majors, and literary works are an important basis for learning literature introduction and modern literature and other related courses. If you can't accurately grasp literary works, you can't fully understand literary history, and vice versa. The two complement each other.

\subsection{Lagging in teaching methods}

Most of the Ancient Chinese literature courses are arranged by writers and stages. Although this helps students to sort out the development of literary history and the characteristics of literary works at different stages, it will lead to the lack of integrity in the teaching of ancient Chinese literature. That is to say, it is difficult for students to form a complete framework for the whole history and works of ancient Chinese literature, and not conducive to the effective improvement of students' literary literacy.

\subsection{Neglecting the aesthetic value of ancient literature}

In the actual teaching process, Ancient Chinese literature teachers generally pay too much attention to the social value and literary value carried by literary works, while ignoring their aesthetic value. On the one hand, it is easy to lead the teaching of ancient Chinese literature into the secular discussion of literature, and ignore the cultural heritage and spiritual heritage of the literary sequel. On the other hand, teachers of ancient Chinese literature in some colleges and universities in our country are used to presenting some advanced research problems in the classroom. Although this can help students understand the frontier theory of the discipline to a certain extent, it is easy for students to ignore the details of ancient literature, which is not conducive to the cultivation of students' aesthetic quality.

\section{The improvement strategy of ancient Chinese literature teaching under the new educational concept}

\subsection{Restoring the original appearance of literature}

Literature is the most real and direct expression of human feelings. At the same time, the process of learning Ancient Chinese literature is a process of dialogue with ancient sages, which helps to improve students' moral character and cultural self-cultivation. Therefore, the teaching of ancient literature in colleges and universities should restore the original appearance of literature to guide students to feel the author's thoughts and feelings through literary works. For example, in the teaching of "Mencius with All One's Heart", teachers can closely connect with students' life reality, so that students can have a deeper understanding and feeling of the content of the work through their own perception. This not only achieves the teaching purpose of teaching and educating people, but also promotes the traditional Chinese virtues.

\subsection{Strengthening the promotion of ancient Chinese literature teaching}

Colleges and universities in China can use information technology to promote the teaching of ancient Chinese literature. For example, we can build a WeChat official account and micro-blog number to promote ancient Chinese literature, which can imperceptibly improve students' enthusiasm and desire for ancient Chinese literature study. In addition to students, there are also people and fields from all walks of life that use the network to promote. Colleges and universities make more targeted teaching programs through the information they feedback, so as to achieve better teaching effect.

\subsection{Elaborately designing the teaching content}

Due to the characteristics of teaching content, long time span and long distance from today's society, as well as the reduction of teaching hours, students are more difficult to learn and the teaching effect is not significant. In order to achieve better teaching effect, teachers must carefully design the teaching content. It's necessary to reasonably integrate the teaching content, the key knowledge related to the basic structure of the course should be explained in depth and thoroughly, which is not limited to the content of the textbook, and should be expanded appropriately when necessary.

\subsection{Establishing network teaching platform}

Due to the epidemic situation, network teaching has been widely valued and used, but at present, most of the ancient 
Chinese literature teachers in our country still use the traditional teaching mode, which will not only increase their own teaching tasks, but also students' learning pressure and difficulty. Therefore, colleges and universities should actively establish network teaching platform in the future, which can not only effectively expand students' learning resources and save teaching resources, but also create a more relaxed and pleasant classroom atmosphere for students. At the same time, teachers and students can also use the network teaching platform to interact anytime and anywhere, so as to answer questions and solve doubts for students in time. Therefore, the establishment of network teaching platform can solve the problem of low teaching efficiency to a certain extent.

\subsection{Constructing diversified course structure system}

The structure of Ancient Chinese literature course in most colleges and universities in China is relatively monotonous. Basically, students' ancient Chinese literature literacy is cultivated and improved through the teaching of literary history and the study of literary works. However, with the development and reform in the field of education, colleges and universities should add some elective courses related to professional knowledge learning as teaching aids, so as to construct a complete course structure system to meet the individual learning needs of different students.

\subsection{Exploring the practical significance of ancient Chinese literary works}

When carrying out the teaching activities of ancient Chinese literature, teachers should focus on the practical significance to explore and analyze works, so as to achieve the teaching purpose of cultivating students' humanistic quality and building students' spiritual civilization. First of all, teachers should connect literary works through the teaching method of combining point and area, to further show students the connotation of ancient Chinese literary works. Secondly, teachers can divide the students into several groups, and let them discuss, analyze and summarize some classic Ancient Chinese literature works, in order to cultivate and improve their ability to discover and solve problems, as well as effectively expand their knowledge reserves and knowledge.

\subsection{Setting up the new concept of ancient literature teaching}

The so-called "new concept of ancient literature teaching" is to explain the humanistic connotation of ancient literary works from a contemporary perspective and consciousness, so as to make the ancient literature have a certain connection with the actual society, and at the same time, it has a certain practical significance for students' real life while imparting relevant knowledge. For example, in the process of teaching poetry in the early Tang Dynasty, the teacher can simply introduce the life of the poet. Taking Chen Ziang, a poet of the early Tang Dynasty, as an example, when explaining his poems, the teacher can introduce all the efforts he has made to fulfill his life ambition to the students. His experience will have a good inspiration for the students who are eager to achieve success. The author thinks that through this kind of explanation, we can make the sages in ancient Chinese literature works have practical contact with students' real life, so as to close the relationship between ancient Chinese literature and the real society, and then help to improve students' interest in learning ancient literature and research desire, in order to ultimately achieve the teaching purpose of improving their literary literacy.

\section{Conclusion}

In conclusion, the knowledge and cultural heritage contained in ancient Chinese literature will have a profound and positive impact on the students' career path and the direction of life development in the future, and will help to promote the development of students' sound personality. Therefore, the majority of university teachers in China should constantly actively explore the effective methods of teaching ancient Chinese literature, and cultivate talents with both professional skills and cultural literacy for promoting the sustainable development of society.

\section{References}

1. She C. Problems existing in the teaching of ancient Chinese literature and the reform ideas. Literature Education 2020; 1(09): 64-65.

2. Wang P, Yi X. The way to construct the effective classroom of ancient Chinese literature. Quality Education in Western China 2020; (16): 115-116.

3. Ma S. Dilemma and countermeasures of ancient Chinese literature teaching in higher vocational colleges. Journal of Jinan Vocational College 2019; (06): 53-55. 